\title{
Preserving the Bone Around the Neck of the Implant, a Critical Factor in Long Term Aesthetic Stability
}

\author{
Howard Gluckman
}

Published online: 12 November 2014

(C) Indian Prosthodontic Society 2014

In 1986 Albrektsson and Zarb came out with their now famous list of success criteria that forms the backbone of our determination of survival versus success in implantology. One of the main factors in this list was the "normal" loss of bone to the first thread and then the loss of $0.2 \mathrm{~mm}$ of bone per year thereafter. For many years we accepted this as gospel and an implant was deemed successful even with this loss of bone. The issue of bone loss was not a problem at all in most cases as it still meant that the implant was stable long term and in cases where the implant was correctly positioned and where there was a thick gingival morphotype there was no shine through of the metal from the implant or recession and exposure of the implant head. However in cases of malposition or thin gingival morphotype or in multiple implant or full arch cases where collapse of the bone and soft tissue is more pronounced. There is potential for a huge aesthetic complications in the aesthetic zone as the head of the implant could expose slowly over time with very little that could be done except perhaps prepping the implant itself, removing the implant and replacing it with one in a better position or in certain single tooth cases coronally repositioned graft to cover the exposed implant head. In the posterior areas and the anterior lower jaws there is also the issue of loss of attached gingiva and with subsequent muscle pull could lead to further bone loss as well as periimplantitis.

The loss of bone was not very well understood until some studies by Hermann in 2001 showed that implants with micro motion between the abutment and the implant was the cause of the bone loss and if the micro motion was eliminated then then there would be no bone loss at all.

H. Gluckman $(\bowtie)$

Cape Town, South Africa

e-mail: docg@mweb.co.za
This was also shown in certain implant types that had morse taper connections that had no opening and closing of the micro gap between the implant and abutment interface whereby there was no bone loss at all and in fact the bone grew over the neck of the implant.

The explanation for this was that the movement of the components and the subsequent pump action creating a flow of toxins and bacteria in and out of the implant screw well (hence the putrid smell). The body subsequently resorbed the bone and deposited connective tissue and epithelium to protect the bone from these insults. In essence a biological width was set up by the body.

In 2006 the term platform switching was first used by Lazzara to describe a situation where the abutment that was placed on the implant was smaller in diameter than the implant which resulted in what looked like a misfit. The result of this was that the bone level on the implant did not recede to the first thread anymore but rather stayed at the neck of the implant. The explanation for this was the fact that the biological width had been switched from vertical to horizontal and as a result there was no longer any bone loss on the implants. This has added benefit as when implant are placed next to each other there is no bone loss between the implants even if they are placed too close together. Implants with cone connections or morse taper connections have a natural build in Platform switch.

The benefit of not having any bone loss around the neck of the implant means that the stability of the soft tissue is more predictable and the risk of gingival recession and exposure of the abutment and the implant neck is radically reduced.

Despite this the correct 3D positioning of the implant as described by Covani is still critical to ensure that the there is minimal soft tissue recession especially in high aesthetic areas and thin gingival morphotypes. The maintenance of 
the bone over the shoulder of the implant also implies that there is less risk of shine through of the implant if it is covered in bone.

Platform switching and the use of implants with cone connections or morse taper connections are essential in cases were aesthetics are important. Using an implant that cannot be platform switched will lead to unnecessary bone loss and may spell disaster in the aesthetic zone in the long term. The posterior areas are not as important but it is still ideal to use an implant that allows the platform switch either naturally like a cone connection or a morse taper or an implant that can accommodate a smaller abutment in order to platform switch the implant and preserve bone.

\section{References}

1. Albrektsson T, Zarb G, Worthington P, Eriksson AR (1986) The long-term efficacy of currently used dental implants: a review and proposed criteria of success. Int J Oral Maxillofac Implants 1(1):11-25

2. Kan JY, Rungcharassaeng K, Lozada JL, Zimmerman G (2011) Facial gingival tissue stability following immediate placement and provisionalization of maxillary anterior single implants: a 2- to 8-year follow-up. Int $\mathrm{J}$ Oral Maxillofac Implants 26(1): $179-187$

3. Chen ST, Buser D (2014) Esthetic outcomes following immediate and early implant placement in the anterior maxilla-a systematic review. Int J Oral Maxillofac Implants 29(Suppl):186-215. doi:10.11607/jomi.2014suppl.g3.3

4. Evans CD, Chen ST (2008) Esthetic outcomes of immediate implant placements. Clin Oral Implants Res 19(1):73-80 Epub 2007 Oct 22

5. Hermann JS, Schoolfield JD, Schenk RK, Buser D, Cochran DL (2001) Influence of the size of the microgap on crestal bone changes around titanium implants. A histometric evaluation of unloaded non-submerged implants in the canine mandible. J Periodontol 72(10):1372-1383

6. Abboud M, Koeck B, Stark H, Wahl G, Paillon R (2005) Immediate loading of single-tooth implants in the posterior region. Int J Oral Maxillofac Implants 20(1):61-68

7. Broggini N, McManus LM, Hermann JS, Medina R, Schenk RK, Buser D, Cochran DL (2006) Peri-implant inflammation defined by the implant-abutment interface. J Dent Res 85(5):473-478

8. Lazzara RJ, Porter SS (2006) Platform switching: a new concept in implant dentistry for controlling postrestorative crestal bone levels. Int J Periodontics Restor Dent 26(1):9-17

9. Weng D, Richter EJ (2005) Die Implantaat-abutment-Verbindung-vom mechanischen zum biologischen Aspekt des Mikrospalts. Implantologia 13(2):125-130

10. Covani U, Cornelini R, Calvo JL, Tonelli P, Barone A (2010) Bone remodeling around implants placed in fresh extraction sockets. Int J Periodontics Restor Dent 30(6):601-607 